\title{
THE OTHER SIDE OF THE COIN: EXAMINING MOBILE GAMES AS A LEISURE CONSTRAINTS
}

\begin{abstract}
The concept of recreation with its dynamic structure and the elements of recreational needs were heavily influenced by communication technology especially after the 2000s (Torkildsen, 2005; Torkildsen, 2012; Spracklen, 2015; Sintas, de Francisco, \& Álvarez, 2015; Choi \& Dattilo, 2017; Valtchanov \& Parry, 2017). The game, one of the oldest known leisure activities (Spracklen, 2011), has been moved from offline to online and further into computers and mobile devices in the 21st century (Chen \& Leung, 2016). The preference of mobile games, which have become one of the most popular entertainment tools due to the growing popularity of mobile devices and applications, has made the concept of leisure more digital than ever (Spracklen, 2015; Redhead, 2016; Pink, Hjorth, Horst, \& Nettheim, 2017). There are great similarities and common points between the motivations of individuals to participate in leisure activities and the motivation to play mobile games. From this point forth; mobile games, which can be regarded as a recreational activity, can also be considered as leisure constraints from the point of leisure evaluation view (Crawford, Jackson, \& Godbey, 1991; Tsai \& Coleman, 1999). The aim of this study is to show the possibility of evaluating mobile games, having a very important place in the digital world and game market, as a leisure constraint in the with the help of literature review.
\end{abstract}

Key words: Leisure constraints. Game. Mobile Game

\section{Cite it like this:}

Yüce, A., Büyükakgül, Ü., Katırc1, H., \& Gökce Yüce, S. (2018). The Other Side of The Coin: Examining Mobile Games as a Leisure Constraints. PODIUM Sport, Leisure And Tourism Review, 7(2), 193-206. https://doi.org/10.5585/podium.v7i2.292

\footnotetext{
${ }^{1}$ Research Assistant at Eskisehir Technical University. Faculty of Sport Sciences, Department of Sports Management, (Turkey). E-mail: arifyuce@ anadolu.edu.tr, ORCID ID: https://orcid.org/0000-0003-3756-3870

${ }^{2}$ Research Assistant at Eskisehir Technical University. Faculty of Sport Sciences, Department of Sports Management, (Turkey) E-mail: uc buyukakgul@anadolu.edu.tr, ORCID ID: https://orcid.org/0000-0002-9463-3073

${ }^{3}$ Associate Professor at Eskisehir Technical University. Faculty of Sport Sciences, Department of Sports Management, (Turkey). E-mail: hakankatirci@anadolu.edu.tr, ORCID ID: $\underline{\text { https://orcid.org/0000-0002-2337-7711 }}$

${ }^{4}$ Research Assistant at Eskisehir Technical University. Faculty of Sport Sciences, Department of Sports Management, (Turkey). E-mail: sgokce@ anadolu.edu.tr ORCID ID: https://orcid.org/0000-0002-2279-2139
} 


\section{EXAMINANDO JOGOS MÓVEIS COMO RESTRIÇÕES DE LAZER}

\section{RESUMO}

O conceito do recreio com a sua estrutura dinâmica e os elementos das necessidades recreativas foram fortemente influenciados pela tecnologia da comunicação especialmente depois da década 2000s (Torkildsen, 2005; Torkildsen, 2012; Spracklen, 2015; Sintas, de Francisco, \& Álvarez, 2015; Choi \& Dattilo, 2017; Valtchanov \& Parry, 2017). O jogo, uma das atividades recreativas conhecidas mais antiga (Spracklen, 2011), foi movido desde offline até online e depois nos computadores e dispositivos móveis no seculo 21. (Chen\&Leung, 2016). A preferência pelos jogos para telemóvel, que se tornaram uma das mais populares ferramentas de entretenimento devido á crescente popularidade dos dispositivos móveis e das aplicações, tornou o conceito de lazer mais digital do que nunca (Spracklen, 2015; Redhead, 2016; Pink, Hjorth, Horst \& Nettheim, 2017). Há grandes similaridades e pontos em comum entrea motivação de indivíduos para participar em atividades de lazer e a motivação para jogar com jogos para telemóvel. Desde este ponto adiante; jogos para telemóvel, que podem ser considerados como uma atividade recreativa, podem ser também vistos como restrições da diversão desde o ponto da perspectiva da avaliação do lazer (Crawford, Jackson, \& Godbey, 1991; Tsai \& Coleman, 1999). O objetivo deste estudo é de demonstrar a possibilidade de avaliar jogos para telemóvel, tendo um lugar muito importante no mundo digital e no mercado dos jogos, como uma restrição da diversão à luz da revisão da literatura

Palavras-chave: Restrições da diversão. Jogo. Jogo para telemóvel

\section{EXAMINAR JUEGOS MÓVILLES COMO RESTRICCIONES DE OCIO}

\section{RESUMEN}

El concepto de recreación con su estructura dinámica y los elementos de las necesidades recreacionales fueron gravemente influenciados por la tecnología de la comunicación, especialmente después de los 2000 (Torkildsen, 2005; Torkildsen, 2012; Spracklen, 2015; Sintas, de Francisco, \& Álvarez, 2015; Choi \& Dattilo, 2017; Valtchanov \& Parry, 2017). El juego, una de las más antiguas y conocidas actividades de ocio (Sparcklen, 2011), se ha movido de un mundo offline a uno online, dentro de aparatos móviles y ordenadores en el siglo XXI (Chen \& Leung, 2016). La preferencia por juegos móviles, se ha convertido en una de las herramientas de entretenimiento más populares debido a la creciente popularidad de estos aparatos y aplicaciones móviles, ha hecho que el concepto de ocio sea más digital que nunca (Sparcklen, 2015; Redhead, 2016; Pink, Hjorth, Horst, \& Nettheim, 2017). Hay grandes similitudes y puntos en común entre las motivaciones individuales para participar en actividades de ocio y la motivación de jugar a juegos móviles. Desde este punto en adelante; los juegos móviles, que pueden ser considerados como una actividad recreacional, pero también pueden ser considerados como una restricción al ocio desde el punto de vista de la evaluación del mismo (Crawford, Jackson, \& Godbye, 1991; Tsai \& Coleman, 1999). El objetivo de este estudio es mostrar la posibilidad de evaluar los juegos móviles, teniendo un lugar muy importante en el mundo digital y en el mercado de juegos, como una restricción al ocio a La Luz de la revisión de la literatura.

Palabras clave: Restricciones de tiempo libre. Juego. Juego móvil 


\section{INTRODUCTION}

It can be said that leisure has a meaning varying according to age, sex, marital status, personal need, desires etc. It also has a structure that can be shaped according to several variables and technological developments. So it can be said that it has dynamic meaning varying from period to period (Raymore, Godbey, \& Crawford, 1994; Cushman, Veal, \& Zuzanek, 2005; Henderson \& Shaw, 2006; Hochschild \& Machung, 2012; Abbott-Chapman \& Robertson, 2015). Physical and digital environments offer unique options for people to do in leisure time (Layland, Stone, Mueller, \& Hodge, 2015). In this context; it is possible to say that digital and mobile technologies are among the most important leisure tools. Digital and mobile technologies have become irreplaceable part of daily life and are seen as routine. Mobile devices that are chosen among mobile technologies are the primary tools for users to keep themselves busy anytime and anywhere. Especially the mobile games are preferred primarily among other applications. Researches (Nysveen, Per Pedersen , \& Thorbjørnsen, 2005; Nielsen, 2011; Mintel, 2015; Statista, 2017a) have shown that mobile games have important place in using mobile devices. In addition, various industrial and scientific studies on mobile games are being made by different disciplines. However, these studies are not including negative effects of mobile games to leisure preference. This study aimed to examine these negative effects in the sense of leisure constraints. From this perspective, there is a possibility for mobile games to be examined under the context of leisure constraints that is defined in various researches by Crawford, Jackson and Godbey as various limits and difficulties affect participation of individuals to leisure activities (Crawford \& Godbey, 1987; Jackson, 1988; Crawford, Jackson, \& Godbey, 1991; Jackson, Crawford, \& Godbey, 1993). In the light of these information, this research aims to evaluate mobile games that have important place in the digital world and game markets as leisure constraints rather than a leisure, with the help of literature review.

\section{THEORETICAL FOUNDATIONS}

The concept of recreation, based on the evaluation of leisure, has become a phenomenon that communities need together with evergrowing and changing conditions. The concept of recreation is seen as an important tool to improve the social values of individuals as well as positive effects on mental and physical health (Pieper, 1998; Torkildsen, 2005; Torkildsen, 2012). It can be argued that the concept of recreation has a dynamic structure in the sense that individual satisfaction for leisure varies according to the desires and needs of the people and shelters intensely personal preferences (Beard \& Ragheb, 1980; Mannell \& Kleiber, 1997; Pereira \& Long, 2015). Aforementioned dynamic structure, which is influenced by almost every area, has been heavily influenced by communication technology especially after the 2000s (Choi \& Dattilo, 2017). Internet, digitalization and mobile technologies, which can be described as the pioneers of change, do not only penetrate into everyday life but also offer a transformation in social life by changing the behavior and attitudes of the individual (Wei \& Lu, 2014; Choi \& Dattilo, 2017).

In general, although the elements of recreational needs (Torkildsen 2005; Torkildsen, 2012) that assessed under the headings of acquiring new experiences, awareness, identity, responsibility and social interaction, mental activity, creativity, physical activity and vitality, the form and choice of satisfying each need tend to change from day to day (Spracklen, 2015; Sintas, de Francisco, \& Álvarez, 2015; Valtchanov \& Parry, 2017). The concept of game, which has a very important place in the concept of recreation since its existence and considered as one of the oldest leisure activities (Spracklen, 2011; Huizinga, 2014), is experiencing the process of change simultaneously with technology. Although the 
game shelters internal motivations such as escaping from the modernity vehicles, as of today it is unimaginable to think the game is independent of the technology. The game, which described as an old behavior, played by gravel or bones in the cave by prehistoric people and this behavior, has been moved from offline to online and further into computers and mobile devices in the 21 st century (Chen \& Leung, 2016).

Mobile gaming has become one of the most popular entertainment tools due to the growing popularity of mobile devices and applications; in short, mobile applications can be described as applications in computing devices that have wireless communication functionality (Jeong \& Kim, 2009; Bose \& Yang, 2011). As of today, mobile games are offered to consumers with versions of other game platforms (game consoles, computers) as well as their own applications. Although some games seem complicated in their style and play format, mobile games are often classified as casual games (Koivisto, 2007). In addition, the fact that mobile games offer instant entertainment-focused and simpler game play compared to games on other platforms also eliminates the need for special skills or expertise to play these games (Koivisto, 2007). All of these situations have contributed to the rapid spread of mobile games, their preference, and the steady rise of mobile games by users and sector (Kang, Ha, \& Hambrick, 2015)

The evaluation of some data related with mobile games will help to understand better where mobile games are coming from. Accordingly, in the research conducted by Nysveen, Per Pedersen , \& Thorbjørnsen (2005), it is stated that consumers primarily prefer to use entertainment and game services although they use all services of mobile devices. The data from the Nielsen (2011) research and Statista (2017a) also reveals that despite the fact that in recent years, individuals still mostly prefer gaming services. According to the year 2017, mobile games are the most downloaded category with the highest rate of $25.08 \%$ in all categories. According to the Global Gaming
Market 2017 report, mobile games, which account for $42 \%$ of the gaming market, are the most profitable segment with annual revenue growth of $19 \%$. It is also anticipated that the mobile game market will dominate more than $50 \%$ of the market by 2020 (Newzoo, 2017). While the number of mobile phone gamers is 180.4 million in the United States by 2016 , the most preferred game types are the puzzle, adventure and strategy games. Individuals indicated that they play games in their leisure time, $18 \%$ said they play at work and $30 \%$ played in a toilet. In addition to this information, $29 \%$ of the individuals spend 3-5 hours a week on mobile games (Statista, 2016a; Statista, 2016b). In addition to mobile phones, the number of players playing on tablets is 126.2 million by 2017 (Statista, 2016c).

The preference of mobile gaming applications as a priority, lead the concept of leisure to become more digital than ever and offers a wide range of options for individuals (Spracklen 2015; Redhead 2016; Pink, Hjorth, Horst, \& Nettheim, 2017). There are great similarities and common points between the motivations of individuals to participate in leisure activities and the motivation to play mobile games. According to this, it can be assumed that the concepts of happiness, satisfaction, freedom, and social interaction, which form the basis of leisure participation motivation, are also the motivation for playing mobile games (Parker, 1979; Nysveen, Per Pedersen , \& Thorbjørnsen, 2005; Torkildsen, 2005; Ha, Yoon, \& Choi, 2007; Torkildsen, 2012; Engl \& Nacke, 2013; Lee \& Quan, 2013; Merikivi, Tuunainen , \& Nguyen, 2017). From this point of view, mobile games, which can be expressed as a leisure activity, are also confronted as a leisure constraint from another point of view.

Leisure constraints can be expressed as various limitations and difficulties that affect the participation and satisfaction of individuals in their leisure activities (Crawford, Jackson, \& Godbey, 1991; Tsai \& Coleman, 1999). Jackson (1988), however, expresses that leisure constraints are the main limiting factors that 
limit individuals' participation in leisure activities, and they divide these constraints into two groups; internal and external. While internal constraints arise from individual's status, capacity, knowledge, gender, age, and interpersonal relationships and external constraints arise from environmental factors, transportation, economic status, social and demographic structure, time and money (Chubb \& Chubb, 1981; Franken \& Raaij, 1981).

According to Crawford \& Godbey (1987), leisure-time constraints can be hierarchically grouped into three groups. These are; internal constraints that include the individual's mood, motivations and attitudes to participation, interpersonal constraints arising from the clash of different characters and features, and places such as open / closed area, facilities, etc. that may affect the expectations, demands and motivations of the people on their leisure preferences and further the structural constraints that contain all the factors related to these areas (Figure 1).

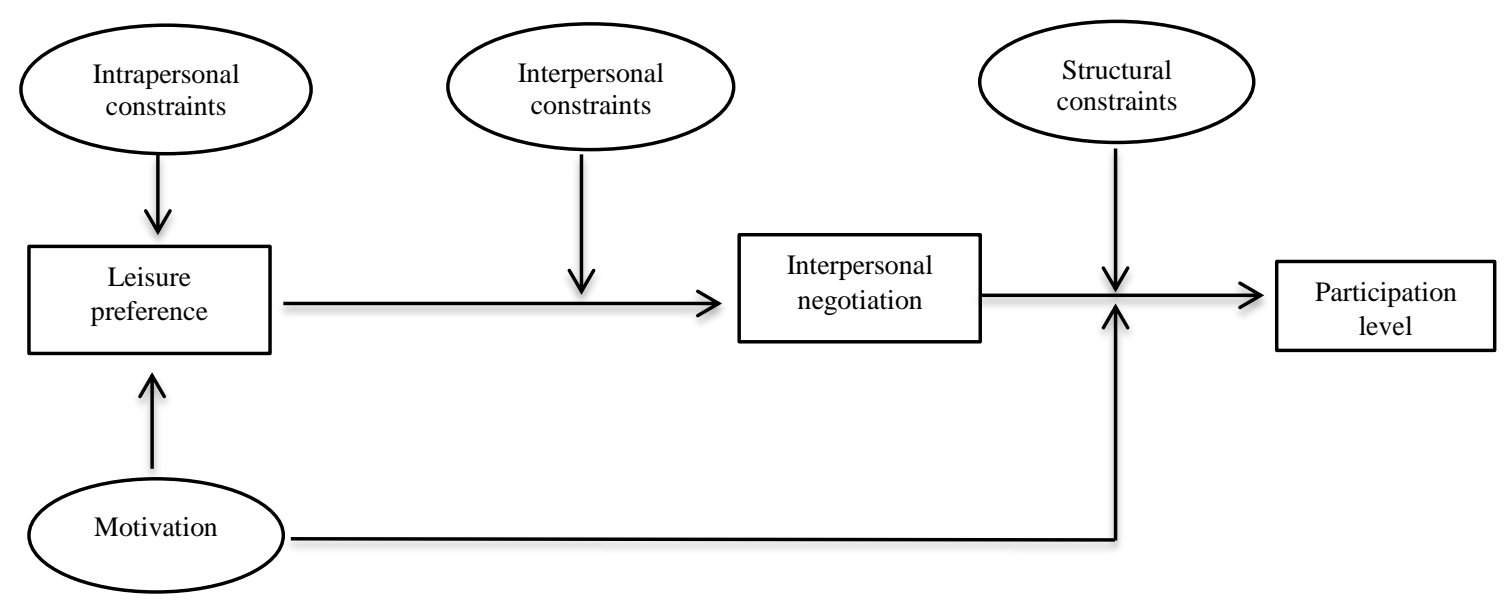

Figure1. The hierarchical model of leisure constraints (Jackson, Crawford, \& Godbey, 1993)

Jackson, Crawford, \& Godbey (1993), points out that there is a hierarchical and interrelated relationship between constraints, according to the model of leisure constraints. According to this, it is possible to say that participation and personal restraints affect the leisure preferences of people. Although the final stages of the hierarchically progressive process is the structural constraints that include physical elements, the overcoming those constraints are also important factors that affect the level of participation. In addition, motivation for leisure activities has an important role in the effectiveness of constraints (Carroll \& Alexandris, 1997). In parallel with this information, it is thought that the motivations for mobile games that people prefer in their leisure can be regarded as a constraint and a different point of view can be given to leisure constraints.

In the light of this information, the aim of this study is to show the possibility of evaluating mobile games, which have a very important place in the digital world and game market, as a leisure constraint in the light of literature review.

\section{METHOD}

In this research that aims to evaluate mobile games as leisure constraints, literature review method was used and the information gathered were interpreted as compilation.

It is accepted that literature review method can be used as base for solving problems and future researches (Cooper, Hedges \& 
Valentine, 2009). In other words, literature review method is a reliable method to describe the conceptual context of the researched area as a whole and to develop a theory or to contribute to existed ones (Meredith, 1993; Richards, 2015; Walliman, 2017; Lune \& Berg, 2017). Webster \& Watson (2002) describe literature review as analysing past to prepare future. In this context; literature reviews that make it possible to evaluate mobile games as leisure constraints rather than leisure activity are important to provide basis for future studies and to develop different theories. On the other hand, accepting mobile games as leisure constraints make this research important to understand features of digitalization world and the processes created by these features. In this research, 6 steps suggested by Machi \& McEvoy (2016) were used in the literature review. These six steps are as follows;

$\begin{array}{ll}\text { 1. } & \text { Select a topic } \\ \text { 2. } & \text { Search the literature } \\ \text { 3. } & \text { Develop the argument } \\ \text { 4. } & \text { Survey the literature } \\ \text { 5. } & \text { Critique the literature } \\ \text { 6. } & \text { Write the review }\end{array}$

The leisure constraints theory that conceptualized in different researches by Crawford, Jackson and Godbey (Crawford \& Godbey, 1987; Jackson, 1988; Crawford, Jackson, \& Godbey, 1991; Jackson, Crawford, \& Godbey, 1993) has provided basis for main research question of this research. Under the context of the relevant theory, mobile games and relevant scientific articles that published in journals abstracting/indexing by international indexes (SCI, SSCI, SCI-E, ESCI, EBSCO, Scopus, etc.), books published by international publishers, reports of globally accepted statistic firms and relevant websites were examined. In the searching process, keywords such as "leisure", "leisure constraints", "mobile technologies" and "mobile game" were used in databases of relevant indexes, online libraries and websites. As a result of these searches, gathered information was archived in digital environment, examined by researches and used to answer the research question.

\section{DISCUSSION}

The concept of leisure has a subjective nature (Mannell, 2013; Zhang, Feng, Lacanienta, \& Zhen, 2017). Therefore, evolving technologies has led to an increase in the options of the time satisfaction. The concept of the game, which has a very important place in the sociology and psychology literature since the existence of mankind, has become a part of everyday life by finding its place in digitalization. In the beginning, it has been stated that the individuals who play mobile games are ordinary players trying to spend time while waiting for something in the daily life or out of boredom and play these games only when they are waiting for something or aiming only to spend time away from professionalism (Koivisto, 2007), today the situation is completely different. Such that, contrary to past times, individuals spend most of their leisure time with mobile games and they have become disoriented in their daily routines.

By year 2017, there are about 2.1 billion mobile game users in the world (Statista, 2017b). Chen \& Leung (2016) found that individuals play online mobile games for an average of 30-45 minutes a day, repeating 3-4 times a day. It is understood that individuals spend 1.5 hours to 3 hours of mobile games in a day. Mobile players, play almost everywhere; at home, at work, at bus stops, etc. It can be interpreted that the fact that mobile players are independent of place in terms of playing games (Kim, 2013; Wei \& Lu, 2014), creates a perception or understanding of being independent of time. This information shows that mobile games are not just played for spending time and that different psychological factors are involved. According to Shaw \& Henderson (2005), state that it is a structural leisure constraint to allocate too much time to the related activity, given that is not an obstacle to leisure activity according to its level of importance. Accordingly, it is possible to say that the increasing tendency to play mobile games creates restrictive element and have an impact on the routine lives of the individuals. 
Although Stenseng, Rise, \& Kraft (2011) talk about how leisure activities focus on goodness, they emphasize the negative aspect that they call darkness. In his work he stated that intensive interest in activities may create obsessions and may even be at the level of dependence. This situation is more evident in digital leisure activities. Similarly, Chen \& Leung (2016) point out that mobile game can be played everywhere, increases the playing time of individuals and that it is an important factor in leading to psychological problems. MorahanMartin \& Schumacher, (2003) mention two different situations related to excessive play of mobile games. The first is that excessive mobile gaming will lead to loneliness, and the second is that people are more inclined to play mobile games. Studies show that mobile games have negative psychological effects on individuals. In this context, psychological problems that may occur in the individuals can be expressed as an example of internal constraints when evaluated in terms of leisure constraints.

Studies (Nysveen, Per Pedersen, \& Thorbjørnsen, 2005; Ren, Kraut , \& Kiesler, 2007; Engl \& Nacke, 2013; Su, Chiang, Lee, \& Chang, 2016; Lehtonen \& Harviainen, 2016; Merikivi, Tuunainen , \& Nguyen, 2017) show that individuals play mobile games with motivations such as social interaction, competition, talent and entertainment. These motivations enable users become loyal mobile players (Cheung, Lee, \& Jin, 2011; Su, Chiang, Lee, \& Chang, 2016), based on the entertainment they perceive and the level of attention they show. It is possible to say that these motivations are interacting with each other. This behavior, which begins with social interaction and entertainment motivation, can leave its place to competition in time. When mentioned matter matches with the skills of the individual, fun / pleasurable situations emerges and stated as positive difficulty or positive competition (Hoffman \& Novak, 2009). Positive competition, perceived subjectively, is one of the most important points for the user to keep up interest and participation in mobile games. Contrary to these situations, if the game is too difficult or the competition level is too high, the users can be nervous and worried (Merikivi, Tuunainen, \& Nguyen, 2017). At this point, the process that begins with social interaction intention and the will to succeed first involves positive competition and keeps the participation permanent, where as it can create situations that adversely affect the state of being good with the difficulty of the game or competition. In other words, the situation starting with passion is moving towards the point of obsession. Such situations are considered as a leisure constraint in terms of the effect they have on the individual.

Marshall McLuhan (1994) stated that people first shaped tools, and then tools shaped people. This assessment of traditional media has become more acceptable and even supportable with the new media. The widespread use of mobile devices, social media becoming an indispensable part of life (Kozlenkova, Palmatier, Fang, \& Xiao, 2017), indicates that the new media forms a transformational bridge between the industrial society and the postindustrial society (Manovich, 2001). In other words, while the tools vary morphologically and technologically, tools continue to increase their influence of shaping people. An example of this case can also be seen in mobile game applications. So much so that some mobile games (Candy Crush, Farmville, Cityville, Pokemon Go etc.) have some limitations on being active or continuation in the game (Fields, 2014; Soroush, Hancock, \& Bonns, 2014; Chen $\&$ Leung 2016). Since the games offer a time limit or a fee option to continue the game or to activate certain features of the game, individuals tend to play games in that time that the applications offer and even take part in the game at midnight by dividing their sleep instead of playing in their free time. Chick, Hsu, Yeh, \& Hsieh (2015), addressed situations that restricted participation in leisure activities within the context of their psychological, time and health dimensions. The related study also indicates that psychological and health-related situations negatively affect the level of satisfaction obtained as a result of people 
participating in leisure activities. In this context, the time limit for continuing the game or activating certain features of the game is seen as another factor for evaluating mobile games as a leisure constraint. Another limitation is that some of paid add-on features. These games, called the Invest/Express type, are defined as the game style in which players are expected to spend their time in the game world in order to obtain/win prizes for the game, or to deposit their money. In this point, the endeavours of players to gain achievement or prizes can be defined as internal and external constraints under the umbrella of leisure constraints (Chubb \& Chubb, 1981; Franken \& Raaij, 1981; Crawford \& Godbey, 1987; Jackson, 1988).

Mobile games are designed in such a way that users will think and feel that they are very clever by keeping them in the game in the first stage. While the players seem to think that they have passed seemingly difficult parts through their own talents, the games that become harder and harder and the next stages give the users the opportunity to pass the levels by offering paid add-ons or features. This is more common in the game-type called Social Networking Games (SNGs). These games are preferred sizably because individuals compete with their social circles in these games and they make players to be faced with optimal level of difficulties (Chess, 2018). The individual, who sees another person is more advanced than himself or herself, will be more impatient and passionate to get through the next level and opt for spending more time in the game or choose paid options (Dockterman, 2013; Kulabaş, 2013; Sinicki, 2017). This situation can also be evaluated in the context of the elements that form the Fear of Missing Out (FoMO), which emerges in social media environments. FoMo defined as; "a pervasive apprehension that others might be having rewarding experiences from which one is absent" (Przybylski, Murayama, DeHaan, \& Gladwell, 2013). The most negative aspect of FoMO expressed as the uncontrolled consumption of the individual's time. People who experience FoMO generally feel remorse for things they haven't done, spend their time and even feel guilty. In addition, it is stated that FoMO will be one of the reasons for the emergence of depressive or positive mood (Wortham, 2011; Przybylski, Murayama, DeHaan, \& Gladwell, 2013; Hetz, Dawson, \& Cullen, 2015; Beyens, 2016; Wegmann, Oberst, Stodt, \& Brand, 2017; Stead \& Bibby, 2017). Accordingly, it is possible to consider such situations that may arise within the scope of mobile games as a leisure constraint. Whether the individual continues to pay or spends more time in both situations, he/she tends to dedicate himself to the game and become more engaged. At this point, it is possible to say that the concept of leisure, which has a subjective identity, has been differentiated. This means that when the individual has the opportunity for recreational activities, there is a possibility that the time frame will disappear within the consumption patterns, and that these activities are considered recreational consumption than recreational activity (Carr, 2017).

Today, individuals see mobile games as the shortest time and the most accessible leisure activity and these games become more and more important both in the technology and gaming sector, and in the daily lives of individuals. Mobile games addressed with its economic aspect in national and international scientific studies but it is important to address mobile games from psychological and sociological point of view. Mobile games can also be regarded as a leisure constraint with this study and these processes are a scientific phenomenon deserving to be investigated with different methods and dimensions.

In addition, some researches (Eklund, 2016; Chess, 2018) on social aspects of mobile games characterise mobile games as masculine and feminine in respect of their contents. Chess emphasizes that the games have feminine aspects are affecting women's leisure experience and leisure satisfaction. Some researches have shown that (Beranuy, Oberst, Carbonell, \& Chamarro, 2009; Takao, Takahashi, \& Kitamura, 2009; Polo, Mendo, León Del Barco, \& Felipe Castaño, 2017) women are using mobile phones and are 
exposing negative effects of them more than men. Similarly, Oftedal, Kang, \& Schneider (2015), argued that women are exposed leisure constraints more than men. According to this information, if women were spending abnormal times on mobile games, there is a risk for them to transform leisure into leisure constraints. Similar possibilities may be happen for men and these situation requires mobile games are needed to be examined by taking sociologic and psychological variations into consideration.

\section{CONCLUSION}

With the developing technologies, one of the most important realities individuals faced are the change phenomenon. It can be said that the change brought by developing technologies has many abstract and concrete factors. While abstract factors refer to changes in the life of individuals and in their leisure experiences; concrete factors refer to mobile games and devices that make up this research's subject. Various researches were mentioned above have shown that mobile games which is a leisure activity user can easily reach have features that may lead negative effects as much as their positive effects. People's spending abnormal times on mobile games may cause social, economic and psychological problems. All these problems individuals faced may be evaluated as leisure constraints which are various limits and difficulties affect participation of individuals to leisure activities.

This research has shown that mobile games are including some features can be labelled as internal/personal, external, interpersonal and structural constraints. However, it seems that internal/personal and external constraints are coming into prominence. In other words, mobile games are described as leisure constraints because of their competitive and negative effects on individuals' time, economy, mood, social relations and participation motivation.

As a conclusion, it is possible to argue that mobile games have negative effects on daily life even they are not sticked to the time and place and make it possible for people to play them while they are moving. There is a risk for mobile games to transform into obsession from passion because of some factors (competition, ambition, will to succeed etc.). This situation may lead individuals to be put away from society and to become lonely.

\section{Recommendations for Future Studies}

The most important sides of the doing research are creating different perspectives, new information and theories and thus contributing to humanity. In this context, this research has shown that mobile games that are accepted as leisure can also be referred as leisure constraints. This situation deserves to be researched as scientific phenomenon. The research conducted can provide a basis for the future empirical researches about mobile games and leisure constraints. At the same time, it can be accepted as conceptual approach for the theories that will be developed or revised about this subject.

\section{Limitations}

This research is restricted with the information and data obtained from relevant scientific articles that published in journals abstracting/indexing by international indexes, books published by international publishers, reports of globally accepted statistic firms and relevant websites. 


\section{REFERENCES}

Abbott-Chapman, J., \& Robertson, M. (2015). Youth leisure, places, spaces and identity. In S. Gammon, \& S. Elkington, Landscapes of leisure (pp. 123-134). London: Palgrave Macmillan.

Beard, J. G., \& Ragheb, M. G. (1980). Measuring Leisure Satisfaction. . 12(1): 20-33. Journal of Leisure Research, 12(1), 20-33.

Beranuy, M., Oberst, U., Carbonell, X., \& Chamarro, A. (2009). Problematic Internet and mobile phone use and clinical symptoms in college students: The role of emotional intelligence. , 25(5), 1182-1187. Computers in Human Behavior, 11821187.

Beyens, I. F. (2016). "I don't want to miss a thing": Adolescents' fear of missing out and its relationship to adolescents' social needs, Facebook use, and Facebook related stress. Computers in Human Behavior, 64, 1-8.

Bose, I., \& Yang, X. (2011). Enter the Dragon: Khillwar's Foray into the Mobile Gaming Market of China. Communications of the Association for Information Systems, 29, 551-564.

Carr, N. (2017). Re-thinking the Relation between Leisure and Freedom. Annals of Leisure Research,, 20(2), 137-151.

Carroll, B., \& Alexandris, K. (1997). Perception of Constraints and Strength of Motivation: Their Relationship to Recreational Sport Participation in Greece. Journal of Leisure Research, 29(3), 279-299.

Chen, C., \& Leung, L. (2016). Are You Addicted to Candy Crush Saga? An Exploratory Study Linking Psychological Factors to Mobile Social Game Addiction. Telematics and Informatics, 33(4), 1155-1166.

Chess, S. (2018). A time for play: Interstitial time, Invest/Express games, and feminine leisure style. New Media \& Society, 20(1), 105-121.
Cheung, C., Lee, M., \& Jin, X. (2011). Customer Engagement in an Online Social Platform: A Conceptual Model and Scale Development. Thirty Second International Conference on Information Systems, (s. 1-8). Shangai.

Chick, G., Hsu , Y. C., Yeh, C. K., \& Hsieh, C. M. (2015). Leisure Constraints, Leisure Satisfaction, Life Satisfaction, and Self-rated Health in Six Cities in Taiwan. Leisure Sciences, 37(3), 232-251.

Choi , Y., \& Dattilo, J. (2017). Connections Between Media Technology and Leisure: Insights from Aristotle and Heidegger. Annals of Leisure Research, 20(2), 152-168.

Chubb, M., \& Chubb, H. R. (1981). Onethird of Our Time: an Introduction to Recreation Behavior and Resource. New York: Wiley. New York: John Wiley \& Sons Inc.

Cooper, H., Hedges , L. V., \& Valentine, J. C. (2009). The Handbook of Research Synthesis and Meta-analysis. New York: Russell Sage Foundation.

Crawford, D. W., \& Godbey, G. C. (1987). Reconceptualizing Barriers to Family Leisure. Leisure Sciences, 9(2), 119-127.

Crawford, D. W., Jackson, E. L., \& Godbey, G. C. (1991). A Hierarchical Model of Leisure Constraints. Leisure Sciences, 13(4), 309-320.

Cushman, ,. G., Veal, A. J., \& Zuzanek, J. (2005). Leisure participation and timeuse surveys: an overview. In ,. G. Cushman, A. J. Veal, \& J. Zuzanek, Free Time and Leisure Participation: International Perspectives (pp. 1-16). Wallingford: CABI Publishing.

Dockterman, E. (2013, 11 15). Candy Crush Saga: The Science Behind Our Addiction. Retrieved August 10, 2017, from TIME: http://business.time.com/2013/11/15/candy-crushsaga-the-science-behind-our-addiction/ 
Arif Yüce, Ümitcan Büyükakgül, Hakan Katırcı \& Sevda Gökce Yüce

Eklund, L. (2016). Who are the casual gamers? In T. Leaver, \& M. Wilson, Social, Casual, and Mobile Games: The Changing Gaming Landscape (pp. 15-30). New York: Bloomsbury Academic.

Engl, S., \& Nacke, L. E. (2013). Contextual Influences on Mobile Player Experience - a Game User Experience Model. Entertainment Computing, 4(1), 83-91.

Fields, T. (2014). Mobile ve social game design: Monetization methods and mechanics. New York: A K Peters/CRC Press.

Franken, D. A., \& Raaij, W. V. (1981). Satisfaction with Leisure Time Activities. Journal of Leisure Reaserch, 13(4), 337-352.

Ha, I., Yoon, Y., \& Choi, M. (2007). Determinants of Adoption of Mobile Games under Mobile Broadband Wireless Access Environment. Information ve Management, 44(3), 276-286.

Henderson, K. A., \& Shaw, S. M. (2006). Leisure and gender: Challenges and opportunities for feminist research. C. Rojek, S. Shaw, \& A. Veal içinde, A handbook of leisure studies (s. 216-230). London: Palgrave Macmillan.

Hetz, P. R., Dawson, C. L., \& Cullen, T. A. (2015). Social media use and fear of missing out (FOMO) while studying abroad. Journal of Research on Technology in Education, 47(4), 259272.

Hochschild, A., \& Machung, A. (2012). The second shift: Working families and the revolution at home. London: Penguin.

Hoffman, D. L., \& Novak, T. P. (2009). Flow Online: Lessons Learned and Future Prospects. Journal of Interactive Marketing, 1, 23-24.

Huizinga, J. (2014). Homo Ludens Ils 86 (Vol. 3). Oxon: Routledge.

Jackson, E. L. (1988). Leisure Constraints: a Survey of Past Research. Leisure Science, 10(3), 203-215.
Jackson, E. L., Crawford, D. W., \& Godbey, G. (1993). Negotiation of Leisure Constraints. Leisure Sciences, 15(1), 1-11.

Jeong, E. J., \& Kim, D. J. (2009). Definitions, key characteristics, and generations of mobile games. In D. Taniar (Ed.), Mobile computing: Concepts, methodologies, tools, and applications (pp. 289-295). Hershey: IGI Global.

Kang, S. J., Ha, J. P., \& Hambrick, M. E. (2015). A Mixed-method Approach to Exploring the Motives of Sport-related Mobile Applications among College Students. Journal of Sport Management, 29(3), 272-290.

Kim, H. M. (2013). Mobile Media Technology and Popular Mobile Games in Contemporary Society. International Journal of Mobile Marketing, 8(2), 42-54.

Koivisto, E. M. (2007). Mobile Games 2010. Nokia Research Center, 1-21.

Kozlenkova, I. V., Palmatier, R. W., Fang, E., \& Xiao, B. (2017). Online Relationship Formation. Journal of Marketing, 81(3), 21-40.

Kulabaş, Ş. (2013, 12 30). Candy Crush'a Neden Para Ödüyoruz? Retrieved August 8, 2017, from Harvard Business Review Türkiye: https://hbrturkiye.com/blog/candy-crush-a-nedenpara-oduyoruz

Layland, E. K., Stone, G. A., Mueller, J. T., \& Hodge, C. J. (2015). Injustice in Mobile Leisure: A Conceptual Exploration of Pokémon Go. Leisure Sciences, 40(4), 288-306.

Lee, S., \& Quan, C. (2013). Factors Affecting Chinese Ubiquitous Game Service Usage Intention. International Journal of Mobile Communications, 11(2), 194-212.

Lehtonen, M. J., \& Harviainen, J. T. (2016). Mobile Games and Player Communities: Designing for and with Clans. Design Management Review, 27(3), 20-26.

Lune, H., \& Berg, B. L. (2017). Qualitative research methods for the social sciences (9 ed.). Edinburgh: Pearson. 
Machi, L. A., \& McEvoy, B. T. (2016). The literature review: Six steps to success (3 ed.). California: Corwin Press.

Mannell, R. C. (2013). Leisure in the laboratory and other strange notions: psychological research on the subjective nature of leisure. In S. Elkington, \& J. Gammon (Eds.), Contemporary Perspectives in Leisure (pp. 25-39). Routledge. (pp. 25-39). New York: Routledge.

Mannell, R., \& Kleiber, D. A. (1997). A Social Psychology of Leisure. Alberta: Venture Publishing.

Manovich, L. (2001). The Language of New Media. Massachusetts: MIT Press.

McLuhan, M. (1994). Understanding Media: The Extensions of Man. . Massachusetts: MIT Press.

Meredith, J. (1993). Theory building through conceptual methods. International Journal of Operations \& Production Management, 13(5), 311.

Merikivi, J., Tuunainen, V., \& Nguyen, D. (2017). What Makes Continued Mobile Gaming Enjoyable? Computers in Human Behavior, 68, 411421.

Mintel. (2015, August 21). Gamers gone mobile: Half of Americans play video games on mobile devices. Retrieved July 2, 2018, from Mintel: http://www.mintel.com/press-centre/technologypress-centre/gamers-gone-mobile-half-ofamericans-play-video-games-on-mobile-devices

Morahan-Martin, J., \& Schumacher, P. (2003). Loneliness and Social Uses of the Internet. Computers in Human Behavior. 19(6), 659-671.

Newzoo. (2017). Global Games Market Report 2017. Amsterdam; San Francisco: Newzoo. Retrieved from https://newzoo.com/insights/articles/the-globalgames-market-will-reach-108-9-billion-in-2017with-mobile-taking- 42
Nielsen. (2011). The Mobile Media Report: State of The Media Q3 2011. Nielsen. Retrieved from http://cn.nielsen.com/documents/NielsenSocial-Media-Report_FINAL_090911pdf

Nysveen, H., Per Pedersen , E., \& Thorbjørnsen, H. (2005). Intentions to Use Mobile Services: Antecedents and Cross-Service Comparisons. Journal of the Academy of Marketing Science, 33(3), 330-346.

Oftedal, A., Kang, H. K., \& Schneider, I. (2015). Perceptions and responses to conflict: Comparing men and women in recreational settings. Leisure Sciences, 37(1), 39-67.

Parker, S. (1979). The Sociology of Leisure. London: George Allen and Unwin Ltd.

Pereira, A. P., \& Long, J. (2015). The Social Dynamics of Space Constructions and Leisure Lifestyles. In Landscapes of Leisure (pp. 41-54). London: Palgrave Macmillan.

Pieper, J. (1998). Leisure, the Basis of Culture. (G. Malsbary, Çev.) Indiana, South Bend.

Pink, S., Hjorth, L., Horst, H., \& Nettheim, J. (2017). Digital Work and Play: Mobile Technologies and New Ways of Feeling at Home. European Journal of Cultural Studies, 21(1), 26-38.

Polo, D. R., Mendo, L. S., León Del Barco, B. B., \& Felipe Castaño, E. (2017). Mobile Abuse in University Students and profiles of victimization and aggression. Adicciones, 29(4), 245-255.

Przybylski, A. K., Murayama, K., DeHaan, C. R., \& Gladwell, V. (2013). Motivational, emotional, and behavioral correlates of fear of missing out. Computers in Human Behavior, 29(4), 1841-1848.

Raymore, L. A., Godbey, G. C., \& Crawford, D. W. (1994). Self-esteem, gender, and socioeconomic status: Their relation to perceptions of constraint on leisure among adolescents. Journal of Leisure Research, 26(2), 99-118.

Redhead, S. (2016). Afterword: A New Digital Leisure Studies for Theoretical Times. Leisure Studies, 35(6), 827-834. 
Arif Yüce, Ümitcan Büyükakgül, Hakan Katırcı \& Sevda Gökce Yüce

Ren, Y., Kraut , R., \& Kiesler, S. (2007). Applying Common Identity and Bond Theory to Design of Online Communities. Organization Studies, 28(3), 377-408.

Richards, L. (2015). Handling qualitative data: A practical guide (3 ed.). London: Sage.

Shaw, S. M., \& Henderson, K. (2005). Gender analysis and leisure constraints: An uneasy alliance. In E. L. Jackson, \& E. L. Jackson (Ed.), Constraints to leisure (pp. 23-34). State College, PA: Venture Publishing.

Sinicki, A. (2017). How Candy Crush Is Controlling Your Brain - The Psychology Behind Addictive Computer Games. Retrieved August 15, 2017, from Health Guidance: http://www.healthguidance.org/entry/17179/1/How -Candy-Crush-Is-Controlling-Your-Brain--ThePsychology-Behind-Addictive-ComputerGames.html

Sintas, J. L., de Francisco, L. R., \& Álvarez, E. (2015). The Nature of Leisure Revisited: An Interpretation of Digital Leisure. Journal of Leisure Research, 47(1), 79-101.

Soroush, M., Hancock, M., \& Bonns, V. K. (2014). Self-control in casual games: The relationship between Candy Crush Saga ${ }^{\mathrm{TM}}$ players' in-app purchases and self-control. In Games Media Entertainment (GEM), 2014 IEEE (pp. 1-6). IEEE. IEEE (s. 1-6). Games Media Entertainment (GEM).

Spracklen, K. (2011). Constructing Leisure. Basingstoke: Palgrave.

Spracklen, K. (2015). Digital Leisure, The Internet and Popular Culture: Communities and Identities in A Digital Age. . Basingstoke: Hampshire : Palgrave Macmillan.

Statista. (2016a, April). Leading Mobile Game Genres Played by Frequent Gamers in the United States in 2016. Retrieved September 7, 2017, from Statista-The Statistics Portal: https://www.statista.com/statistics/232332/types-ofmobile-games-played-most-often-in-the-us/
Statista. (2016b, March). Statista - The Statistics Portal. Retrieved September 6, 2017, from Number of Mobile Phone Gamers in the United States from 2011 to 2020 (in millions): https://www.statista.com/statistics/234635/numberof-mobile-gamers-forecast/

Statista. (2016c, March). Statista - The Statistics Portal. Retrieved September 6, 2017, from Number of Tablet Gamers in the United States from 2011 to 2020 (in millions): https://www.statista.com/statistics/282443/numberof-tablet-gamers-in-the-us/

Statista. (2017a, July). Most popular Apple App Store categories in July 2017, by share of available apps. Retrieved September 29, 2017, from Statista-The Statistics Portal: https://www.statista.com/statistics/270291/popularcategories-in-the-app-store

Statista. (2017, June). Number of active mobile gamers worldwide from 2014 to 2021 (in millions). Retrieved September 3, 2017, from Statista - The Statistics Portal: https://www.statista.com/statistics/748089/numbermobile-gamers-world-platform/

Stead, H., \& Bibby, P. A. (2017). Personality, fear of missing out and problematic internet use and their relationship to subjective wellbeing. Computers in Human Behavior, 76, 534-540.

Stenseng, F., Rise, J., \& Kraft, P. (2011). The Dark Side of Leisure: Obsessive Passion and Its Covariates and Outcomes. Leisure Studies, 30(1), 49-62.

Su, Y. S., Chiang, W. L., Lee, C. T., \& Chang, H. C. (2016). The Effect of Flow Experience on Player Loyalty in Mobile Game Application. Computers in Human Behavior, 63, 240-248.

Takao, M., Takahashi, S., \& Kitamura, M. (2009). Addictive personality and problematic mobile phone use. CyberPsychology \& Behavior, 5, 501-507.

Torkildsen, G. (2005). Leisure and recreation management (5 ed.). New York: Routledge. 
Torkildsen, G. (2012). Torkildsen's sport and leisure management (6 ed.). New York: Routledge.

Tsai, E. H., \& Coleman, D. J. (1999). Leisure Constraint of Chinese Immigrants: An Exploratory Study. Society and Leisure, 22(1), 243264.

Valtchanov , B. L., \& Parry, D. C. (2017). I Like My Peeps: Diversifying the Net Generation's Digital Leisure. Leisure Sciences, 39(4), 336-354.

Walliman, N. (2017). Research methods: The basics. London: Routledge.

Webster, J., \& Watson, R. T. (2002). Analyzing the past to prepare for the future: Writing a literature review. MIS Quarterly, xiii-xxiii.

Wegmann, E., Oberst, U., Stodt, B., \& Brand, M. (2017). Online-specific fear of missing out and Internet-use expectancies contribute to symptoms of Internet-communication disorder. Addictive Behaviors Reports, 5, 33-42.

Wei, P. S., \& Lu, H. P. (2014). Why do people play mobile social games? An examination of network externalities and of uses and gratifications. Internet Research, 24(3), 313-331.

Wortham, J. (2011, April 10). Feel like a wallflower? Maybe it's your facebook wall. Retrieved June 11, 2017, from The New York Times:

https://www.nytimes.com/2011/04/10/business/10p ing.html

Zhang, W., Feng, Q., Lacanienta, J., \& Zhen, Z. (2017). Leisure participation and subjective wellbeing: Exploring gender differences among elderly in Shanghai, China. Archives of gerontology and geriatrics. 69, 45-54. 